Article

\title{
Transitioning to a Green Economy-Possible Effects on the Croatian Economy
}

\author{
Nada Denona Bogovic ${ }^{1}$ and Zvonimira Sverko Grdic ${ }^{2, *}$ \\ 1 Faculty of Economics and Business, University of Rijeka, 51000 Rijeka, Croatia; nada.denona@ri.t-com.hr \\ 2 Faculty of Tourism and Hospitality Management, University of Rijeka, 51410 Opatija, Croatia \\ * Correspondence: zgrdic@fthm.hr; Tel.: +385-5129-4197
}

Received: 21 October 2020; Accepted: 9 November 2020; Published: 10 November 2020

\begin{abstract}
Following the global economic crisis of 2008, the concept of green economy has become a significant field of interest for scientific research as well as for specific development policies in various countries around the world. More recently, the transition towards green economy has been considered a desirable model and alternative approach to development encompassing all elements of sustainable development-economic, ecological and social. By adopting the 2019 European Green Deal, the European Union has explicitly opted for a new pattern of development that involves all European countries transitioning their economies, i.e., achieving economic growth while significantly reducing their negative environmental impact. The aim of this paper was to assess the possible effects of Croatian economy transitioning in accordance with the European Green Deal strategic framework and resources planned for Croatia in the following EU budgeting period (2021-2027). Based on the regression analysis results and two developed investment scenarios for the green transition, the authors have shown the potential positive effects of such a process on the gross domestic product and on total employment. These results were further supported by arguments based on examples for specific sectors and economic activities. The authors conclude that transitioning towards green economy, i.e., implementing specific green economy policies can serve to push sustainable development in the EU while simultaneously contributing to the implementation of the strategic goals of the European Green Deal.
\end{abstract}

Keywords: green economy; green transition; European Green Deal; sustainable development

\section{Introduction}

The still dominant linear model of economic growth, i.e., the take-make-waste model, has resided on the assumption that natural resources are widely available and limitless since its conception back during the industrial revolution. It has led contemporary civilization to the brink of ecological disaster [1], and it continues to be a hindrance for further economic, social and environmental development [2]. Due to the linear economy model and growing environmental externalities caused by economic reproduction, the world today faces the consequences of the climate and environmental crisis, endangered biodiversity, depletion of non-renewable energy sources and a rise of social inequality [3].

Various sciences, including economics, have thus spent the last four decades searching for different, alternative ideas and adoptable development models that can reduce the pressure that the economy exerts on the environment. The goal is to determine how these alternative models can contribute to solving the complex, global climate and environmental issues $[4,5]$. The theoretical approach to environmental economics and sustainable development has thus led to the development of the concept of "green economy", that proposes tools for solving the lack of balance between economic activities and the state of the environment by achieving economic, social and ecological sustainability. Green economy aims to achieve macroeconomic growth while simultaneously ensuring development 
in the form of employment, reduction in national and regional inequalities, increase of the standard of life and the health of both people and the environment. The EU has recognized green economy and the green growth paradigm as valuable concepts for the long-term growth and development of its members and has based its Europa 2020 Strategy on the principles of green economy [2]. One of the three priorities in the strategy promotes "economy that more efficiently uses resources, that is greener and more competitive" [6]. The document Towards Sustainable Europe by 2030 [7] states the need to transition from linear to circular economy and to ensure sustainable development for the purpose of reducing negative environmental impact. The European Green Deal represents a significant step in the right direction, i.e., towards combating global economic and environmental challenges, and accepting sustainable development and the green economy as future EU developmental paradigms. The Deal, presented to member countries on 11 December 2019, states that it is necessary to transform the EU's economic systems to a "contemporary, resource-efficient and competitive economy that, by the year 2050, has achieved net zero greenhouse gas emissions, that economic growth is not connected to resource use and that no single person or region are neglected" [8]. The European Green Deal, as a strategy for the EU to achieve sustainable economy, is based on a different, alternative approach to economic growth and development compared to the current linear economic model. Such a new, contemporary approach is founded on basic principles of sustainable development and green economy in both concept and implementation.

Croatian economic development is primarily impacted by national politics, followed by EU politics, the World Trade Organization's rules, the International Monetary Fund and other international institutions, and, clearly, trends in global economy and politics [9]. The process of Croatian accession to the European Union was marked by the harmonization of law, liberalization and free trade, which represented the basis for integrating the Croatian economy into the European and global markets. The main economic activities are tourism, industry, civil engineering and agriculture. A six-year recession in Croatia has affected almost every sector of the economy, with one exception-tourism [10]. Croatian economy's existing weaknesses-structural features, regional inequality, low competitiveness and long-term demographic issues-require a complete and systematic approach when it comes to a future development model. Such a model should encompass implementing both the concept and policies of green economy. Future EU funds play an important financial role to this end, as Croatia will have about 22 billion euro at its disposal for the 2021-2027 programme period. Of that total sum, 9.4 billion stems from the Next Generation EU fund for Covid-19 recovery efforts, while the remaining 12.7 billion stems from the EU multiannual financial framework (MFF) intended for funding multiple areas, including transitioning towards a green economy. Projects in Croatia to be funded from the MFF will therefore, to a large extent, be based on green economy and closely related approaches, such as circular economy.

Taking into consideration how exceptionally important these issues are to the future development of all EU member countries, this paper explores the potential effects of implementing a green economy in the Republic of Croatia, i.e., transitioning the current economic structure towards green growth and development. The originality of this paper lies in its effort to assess the possible effects of Croatian economy transitioning in accordance with the European Green Deal strategic framework and resources planned for allocation to Croatia in the following EU budgeting period (2021-2027). Historical data showing the link between investments, macroeconomic GDP indicators, employment and ecological indicators $\left(\mathrm{SO}_{2}, \mathrm{CO}, \mathrm{NO}_{\mathrm{x}}\right.$ and wastewater emissions) were used to create a projection concerning the impact of future investments from the 2021-2027 programme period on the Croatian economy. Based on the regression analysis results and two developed investment scenarios for the green transition, the authors have shown the potential positive effects of drawing EU funds and investing that money in green economy. Following the introduction, the paper continues with an overview of available and relevant literature, where the authors contribute to the existing literature on green economy by presenting both positive and critical points made by various relevant authors, as well as by linking the theoretical/conceptual approach to green economy and growth with the EU's concrete strategic choices. 
The paper then covers the research methodology and statistical analysis, followed by an overview of the obtained results. Based on the knowledge accumulated from the literature, results obtained and features of the Croatian economy, the final section discusses and argues about the possible effects of Croatia transitioning to a green economy through examples from specific sectors and economic activities. Taking into account the complexity of green economy, this paper contributes, furthermore, to the corpus on the subject research, especially from the perspective of the national economy.

\section{Literature Review}

The term green economy first appeared in 1989 in a Report from the London Environmental Economics Centre [11]. According to one of its most cited definitions, green economy results in improving prosperity and social equality while simultaneously reducing pressure on the environment and ecological damage $[12,13]$. This definition presupposes that the features of green economy are low carbon rates, efficient use of natural resources and social inclusion. Regardless of any differing concepts of green economy (Table 1), they are all based on a holistic approach towards the principles of sustainable development, i.e., achieving balance between economic, ecological and social goals.

Table 1. Understanding green economy [14-16].

\begin{tabular}{|c|c|}
\hline Organization & Understanding Green Economy \\
\hline UNEP, 2011 & $\begin{array}{l}\text { One that results in improved human well-being and social equity, } \\
\text { while significantly reducing environmental risks and ecological } \\
\text { scarcities. It is low carbon, resource efficient, and socially inclusive. In a } \\
\text { green economy, growth in income and employment should be driven by } \\
\text { public and private investments that reduce carbon emissions and } \\
\text { pollution, enhance energy and resource efficiency, and prevent the loss } \\
\text { of biodiversity and ecosystem services. }\end{array}$ \\
\hline UNEP, 2009 & $\begin{array}{l}\text { A system of economic activities related to the production, } \\
\text { distribution and consumption of goods and services that result in } \\
\text { improved human well-being over the long term, while not exposing } \\
\text { future generations to significant environmental risks or ecological } \\
\text { scarcities. }\end{array}$ \\
\hline UNCTAD, 2011 & $\begin{array}{l}\text { An economy that results in improved human well-being and reduced } \\
\text { inequalities, while not exposing future generations to significant } \\
\text { environmental risks and ecological scarcities. It seeks to bring long-term } \\
\text { societal benefits to short-term activities aimed at mitigating } \\
\text { environmental risks. A green economy is an enabling component of the } \\
\text { overarching goal of sustainable development. }\end{array}$ \\
\hline Green Economy Coalition, 2011 & $\begin{array}{l}\text { Green economy is a resilient economy that provides a better quality of } \\
\text { life for all within the ecological limits of the planet. }\end{array}$ \\
\hline $\begin{array}{l}\text { International Chamber of } \\
\text { Commerce, } 2011\end{array}$ & $\begin{array}{l}\text { Green Economy is described as an economy in which economic growth } \\
\text { and environmental responsibility work together in a mutually } \\
\text { reinforcing fashion while supporting progress on social development. }\end{array}$ \\
\hline Danish 92 Group, 2011 & $\begin{array}{l}\text { The Green Economy is not a state but a process of transformation and a } \\
\text { constant dynamic progression. The Green Economy does away with the } \\
\text { systemic distortions and dysfunctionalities of the current mainstream } \\
\text { economy and results in human well-being and equitable access to } \\
\text { opportunity for all people, while safeguarding environmental and } \\
\text { economic integrity in order to remain within the planet's finite carrying } \\
\text { capacity. The Economy cannot be Green without being Equitable. }\end{array}$ \\
\hline
\end{tabular}


Table 1. Cont.

\begin{tabular}{cl}
\hline Organization & \multicolumn{1}{c}{ Understanding Green Economy } \\
\hline Government of South Africa, 2011 & $\begin{array}{l}\text { The green economy involves largely new economic activities } \\
\text { and must provide an important entry-point for broad-based } \\
\text { black economic empowerment, addressing the needs of } \\
\text { women and youth entrepreneurs and offering opportunities for } \\
\text { enterprises in the social economy. }\end{array}$ \\
\hline Rio 20+, Objectives and themes of the & $\begin{array}{l}\text { Green economy can be seen as a lens for focusing on and } \\
\text { seizing opportunities to advance economic and environmental } \\
\text { goals simultaneously. }\end{array}$ \\
\hline EEA, 2014 & $\begin{array}{l}\text { A green economy is one that generates increasing prosperity } \\
\text { while maintaining the natural systems that sustain us. }\end{array}$ \\
\hline Diyar, 2014 & $\begin{array}{l}\text { The economy where the growth of the people's welfare and } \\
\text { employment increase are provided owing to the state and } \\
\text { social investments ensuring reduction of emissions and } \\
\text { environmental pollution and stimulating effective use of } \\
\text { energy and resources as well as preventing from any harm to } \\
\text { biodiversity and ecosystem. }\end{array}$ \\
\hline &
\end{tabular}

For the purpose of creating appropriate environmental policies for the British government to use in environmental management, a document was designed titled Blueprint for a Green Economy [17,18]. Apart from the title, the contents do not tackle the features and principles of green economy, but it can be concluded that it represents a part of the theoretical framework of environmental economy and sustainable development. This first document covers the issues concerning the basic principles of environmental economy in detail, it emphasises the importance of sustaining an adequate level of natural resources and it covers defining and implementing anticipatory environmental policies. After this first Blueprint positioned green economy into the theoretical framework of environmental economy and sustainable development, the same authors drafted Blueprint 2-Greening the world economy [19], in which they focused on global environmental issues and threats. Basing their work on the conceptual model of common goods, they showcased the importance of implementing a green economy as a strategic development tool through examples of global warming, environmental degradation in underdeveloped countries, tropical forest devastation and other elements. This was followed by Blueprint 3-Measuring Sustainable Development [20], which proposes a set of indicators for measuring sustainable development in Great Britain. The authors particularly stress the possibility of measuring sustainable development in economic activities suitable for applying green economy-agriculture, recycling, waste management, managing water and forest resources.

The interest in a green economy increased [21], but it was not until the global financial crisis of 2008 that the development and implementation of the green economy concept garnered special attention from both science and politics [13]. The period post 2008 saw the appearance of initiatives, primarily from UNEP, for promoting green economy, such as the Global Green New Deal (GGND) in 2009 [22]. This initiative, coordinated by UNEP, was one of the nine Joint Crisis Initiatives undertaken by the Secretary-General of the UN and his Chief Executives Board in response to the 2008 economic and financial crisis [23]. The aim of this initiative was to emphasize the importance of investing in green sectors such as energy efficient technologies, renewable energy sources, public transportation, sustainable agriculture, environmentally conscious tourism and biodiversity. These investments present an opportunity for national economies to recover, achieve sustainable development, increase competitiveness, open new, decent and quality jobs and workplaces and reduce poverty, while simultaneously solving acute environmental issues. UNEP advocated for so-called green stimulus packages, and key areas were identified where major public investments could pave the way for a green economy [14]. 
The Report Towards a Green Economy [12] argued in detail for the need to change from the so-called brown economy model to a green economy, especially in less developed countries, while it could also be applied to underdeveloped regions within national economies. The Report defines the requirements for transitioning to a green economy, such as changing the institutional framework or ecological instruments. Transitioning to a green economy is especially applicable for activities stemming from the use of available natural capital—agriculture, fishing, forestry and the water economy. This also includes activities from sectors typically tied to brown economy, such as transportation, energy and processing, as those activities can achieve significant energy use reduction and increase energy and resource efficiency by transitioning to a green economy.

The UN Conference on Sustainable Development in 2012 (RIO+20) defined the possibility to develop a green economy as a key topic, with the aim of achieving sustainable development and reducing poverty, including instruments for supporting developing countries [24-26]. That is how the concept of green economy entered a wider political framework. Even though it was originally quite ambitious, some authors state that the conference did not, in fact, successfully position the concept and policies of green economy at the centre of the relevant international discourse [27-29]. Nonetheless, from the perspective of decision-makers concerning economic policies, green economy is becoming more prominent as a source of new growth and new jobs, as well as the accumulation of wealth. Locally, cities and regions see green economy as both a challenge and an opportunity for transitioning towards sustainable low-carbon and low-resource-intensive communities [30]. That is how transitioning to a green economy contributes to structural economic changes, and it is expected to result in positive macroeconomic effects such as increased employment and gross domestic product.

The need for transitioning to a green economy has thus been globally recognized, and it stemmed from the consequences of the global recession, negative changes in the environment resulting from human activity and great social inequality [31].

A large number of scientific papers and studies indicate that a green economy will have a positive impact on employment, i.e., on creating new green jobs [32-38]. According to these papers, green jobs can be considered as those that significantly contribute to environmental preservation or restoration. More specifically, these are jobs that help with protecting the ecosystem and biodiversity, reduce energy, material and water consumption, result in the decarbonization of the economy and minimize all types of waste and pollution generation [35].

Furthermore, an approach closely tied to the green economy is the one known as green growth. It is based on the assumption that national output, such as the GDP, can increase in conjunction with preserving natural resources and minimizing pressure on the environment $[39,40]$. Such a scenario presupposes the transition of economic activities towards a green economy and sustainable development. UNEP thus states that "Green growth is strictly connected with the idea of green economy oriented at increased overall social welfare and social justice, at the same time considerably reducing environmental risks and ecological deficiencies" [12]. When considering the relationship between green growth, green economy and sustainable development. Kasztelan states that "economic growth which contributes to rational utilisation of natural capital, prevents and reduces pollution, and creates chances to improve the overall social welfare by building green economy, and finally makes it possible to enter on the path towards sustainable development" [16].

The definitions listed in Table 2 further exemplify the relationship of these three approaches. 
Table 2. Select definitions of green growth [41].

\begin{tabular}{|c|c|}
\hline Organization & Select Definitions of Green Growth \\
\hline OECD, 2011. & $\begin{array}{l}\text { "aims to foster economic growth and development, while ensuring that } \\
\text { natural assets are used sustainably, and continue to provide the resources } \\
\text { and environmental services on which our well-being relies ..." }\end{array}$ \\
\hline World Bank, 2012. & $\begin{array}{l}\text { "... growth that is efficient in its use of natural resources, clean in that it } \\
\text { minimizes pollution and environmental impacts and resilient in that it } \\
\text { accounts for natural hazards ..." }\end{array}$ \\
\hline UNESCAP, 2012. & $\begin{array}{l}\text { "... environmentally sustainable economic progress to foster low-emission, } \\
\text { socially inclusive development ..." }\end{array}$ \\
\hline $\begin{array}{l}\text { Global Green Growth } \\
\text { Institute (GGGI), } 2012 .\end{array}$ & $\begin{array}{l}\text { "... new revolutionary development paradigm that sustains economic } \\
\text { growth while at the same time ensuring climatic and environmental } \\
\text { sustainability ..." }\end{array}$ \\
\hline European Commission, 2016. & $\begin{array}{l}\text { "The aim is to create more value while using fewer resources, } \\
\text { and substituting them with more environmentally favorable choices } \\
\text { wherever possible" }\end{array}$ \\
\hline
\end{tabular}

Gissin, Mekhanrseva, Putilina and Surzhikov [42] state that, according to expert estimations, a green economy is capable of rapidly ensuring GDP growth and increasing income per capita and employment. In order to start the transition to a green economy, the authors have found that $2 \%$ of the global GDP in the period 2012-2050 should be invested in agriculture, housing and municipal services, electrical energy economics, fishing, forestry, production, industry, tourism, transportation, waste disposal and recycling, and water resource management [42].

This overview, and the overall literature pertaining to green economy, its theoretical framework and applicable policies, shows that it is a very complex and not fully methodologically developed model. A good example of the systematization and relationship between theory, concept, policies and instruments can be found in the PEER Report, as shown in Figure 1. Its authors, Saikku et al. [15], state that the concept of a green economy can encompass several meanings and be related to different economic theories, concepts, practical approaches and assessment tools. First, the green economy is linked to both theories of environmental economics and ecological economics. The implementation of these two theories has different practical outcomes. Environmental economics is closely related to cleaner production and resource efficiency, whereas ecological economics relies on concepts such as industrial ecology (or circular economy). Waste hierarchy can be related to both, depending on the extent to which it is implemented (downcycling versus upcycling). All these concepts are based on practical approaches or solutions to achieve environmental, economic and social benefits. In addition, in order to measure the effects of these solutions, different assessment tools such as lifecycle assessment can be used.

Even though a significant number of authors view green economy and green growth as a necessary model for transforming the current global economy, there are also papers that are critical of these concepts. For example, Hickel and Kallis [39] state that empirical evidence concerning resource consumption and $\mathrm{CO}_{2}$ emissions does not support the green growth theory. They conclude their research by stating that "green growth is likely to be a misguided objective, and that policymakers need to look toward alternative strategies". Critics of the concept of green economy also state that it overlaps with the principles of sustainable development and finally that it is simply imprecise. Brand [43] states that green economy is yet another oxymoron like sustainable development, as neither term can be properly defined. Lorek and Spangenberg [44] state that the concept of green economy does not support the original sustainability criterion, i.e., the "Brundtland" definition of sustainable development, and that it too heavily relies on optimistic predictions for future technologies. According to the authors, focusing on efficiency and innovation cannot guarantee the realization of the "Brundtland" sustainability criteria. Furthermore, some authors state the possible negative effects of a green 
economy on employment, as creating so-called green jobs can result in existing jobs being removed [45]. Using Spain as an example, it is estimated that 2.2 jobs were destroyed for each green job created, and each green megawatt installed destroyed 5.28 jobs on average elsewhere in the economy [46]. Loiseau [11] argues that despite the popularity of this concept among national and international policy programmes and institutions, its usefulness and appropriateness as a pathway to sustainability remains questionable.

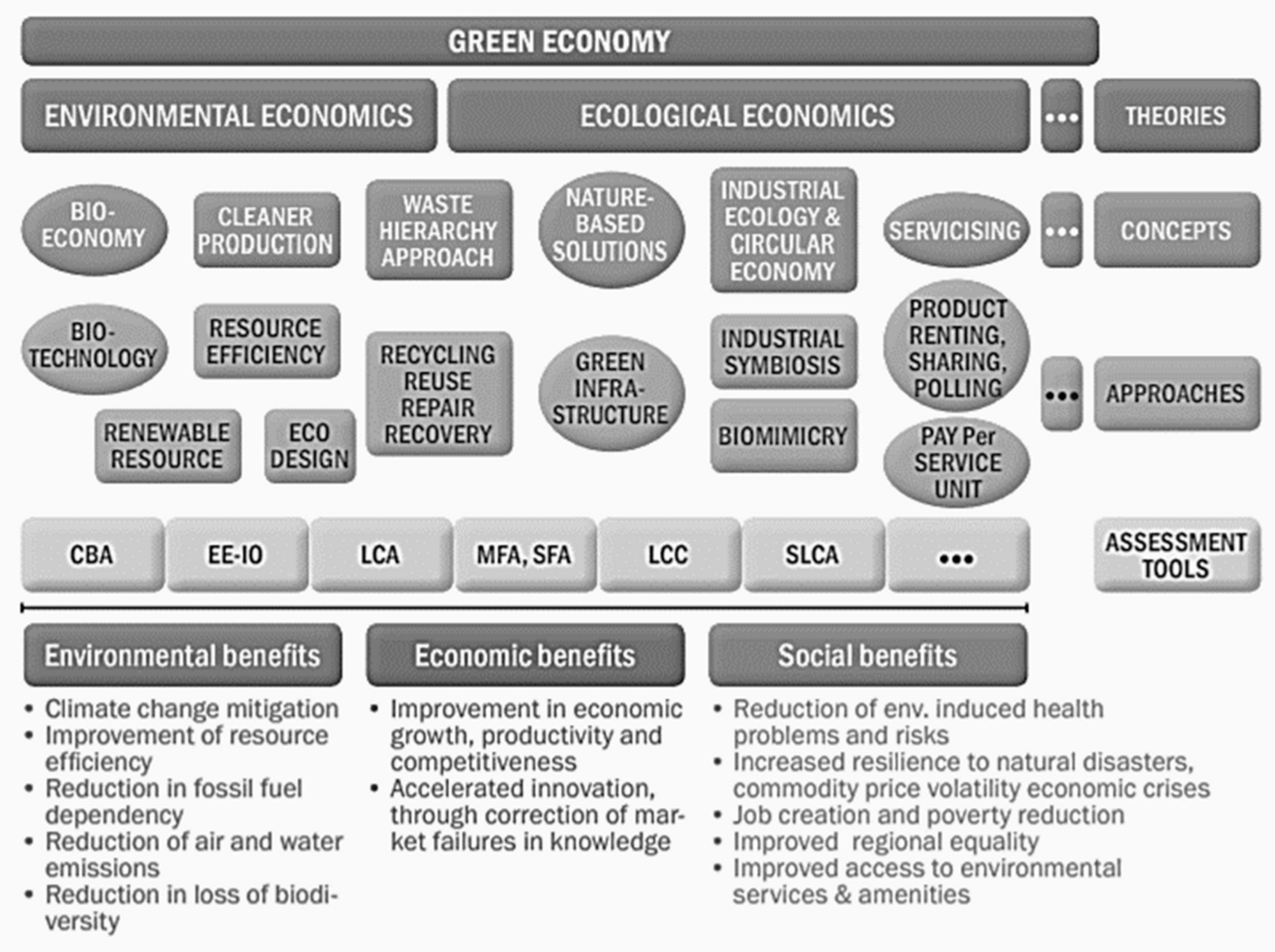

Figure 1. Conceptual framework for implementing a green economy in practice (current concepts are marked with boxes, while emerging concepts are in circles) [43] Legend: abbreviations: CBA (Cost-Benefit Analysis); LCA (Life-cycle assessment); MFA (Material flow analysis); LCC (Life-cycle costing); SLCA (Social life-cycle assessment).

As described by Bailey and Caprotti [47] and Boyd, Boykoff and Newell [48], it is debatable whether the widespread focus on eco-efficiency and decoupling suggests genuinely transformative processes or whether it is simply a renewed attempt to render environmental change and sustainable development less threatening or even profitable for capitalist accumulation strategies. Cook and Smith [49] express similar unease about the limited attention given to inclusivity and social and distributive justice in mainstream readings of the green economy.

However, despite expected critical observations, the fact remains that the concepts of green economy and green growth, i.e., transitioning towards a green economy, continue to gain ground within various scientific disciplines, as well as in politics and business. A prevailing number of scientists and experts nevertheless see the transition towards a green economy as the new paradigm of economic growth and development. They see it as necessary to overcome economic, social and environmental issues that have arisen as consequences of how economic systems have worked so far.

A large number of authors have researched how investments will impact GDP and employment $[50,51]$, but the impact of investments on environmental indicators has not been sufficiently explored. Guo, Qu and Tseng [52] have researched the relationship among technological innovation, environmental regulation and regional green growth performance. When looking into similar matters, 
Kim, Kim and Chae [53] used indicators such as greenhouse gas emissions per unit of GDP and energy consumption per unit of GDP for the purpose of developing an evaluation indicator system for green growth. Mundica, Roman and Cansino [54] apply the indicators of energy intensity and carbon intensity to measure the performance of the Swedish green energy economy. Bilgaev, Dong, Li, Cheng, Sadykova and Mikhevva [55] explore the same topic and used the volume of air, water and waste pollutants per unit of gross regional product. In other words, they use relevant environmental and economic indicators to present the impact of investments on economic and environmental trends.

Research on the relationship between the environment and corporate social responsibility indicates that there is a positive relationship between environmental corporate social responsibility, the effect on corporate performance, consumer surplus and social welfare and the effect on the environment. Most studies agree that ESCR (Environment Social Corporate Responsibility) will promote overall social welfare and improve the environment [56,57]. DiSegni, Huly and Akron [58] explored the relationship between corporate social responsibility, environmental leadership and financial performance. They concluded that companies that are proactive in supporting social responsibility and environmental sustainability are characterized by significantly higher profits than those of the industry and the sector, though not higher than those of the entire market. Even though we previously discussed documents defining the possibility and necessity of implementing a circular economy, we further mention documents pertaining to specific areas. The EU uses a framework of protocols, documents and acts that will enable the easier implementation of a circular economy [59].

In the design and production domain, CE design protocols (EN 45558 and EN 48889) represent a framework for the standard concerning "material efficiency that would establish future eco-design requirements on, amongst others, durability, reparability and recyclability of products". In the product use and consumption domain, Circular Public Procurement was presented as part of green public procurement. In the products' end of life and waste domain, the document European Waste Shipment Regulations outlines the procedures regarding the shipment of waste, but certain "green listed wastes" are exempt, reducing administrative burdens for manufacturers and promoting circularity.

The Republic of Croatia adopted several strategic documents concerning the transition towards a green economy: Strategy for Sustainable Development of the Republic of Croatia [60], Strategic guidelines for the development of green economy-Green development of Croatia [61], Strategy for innovation encouragement of Croatia 2014-2020 [62], Strategy for Smart Specialisation for the Republic of Croatia 2016-2020 [63], Energy Development Strategy of the Republic of Croatia until 2030 with an outlook to 2050 [64]. Those strategic documents visibly show the lawmakers' intention to achieve the goals of sustainable economic, social and environmental development, as well as to meet the EU's standing development plans. The existing strategic framework and specific laws, programmes and plans also lean towards energy and environmentally acceptable activities. Some of these are the Croatian Islands Act [65], Croatian Act on Hill and Mountain Areas [66], Green Tourism Development Action Plan [67], the Integrated National Energy and Climate plan for Croatia 2021-2030 [68]. The most recent document-the National development strategy until 2030, which is currently undergoing public consultation, is an example of how the future regulatory framework is being constructed. One of the strategic goals defined in that document is achieving "Green Croatia". When this strategy is adopted, the next step will be to build an appropriate regulatory framework concerning the transition towards a green economy. The harmonization of various documents across sectors is also expected as a basis for drawing EU funds in the next budgeting period.

In the remainder of this paper the authors move forward from the positive standpoint on green economy as an alternative developmental pattern, as they contemplate and argue for the potential positive effects of implementing the concept of green economy on the Croatian economy. The recently adopted European Green Deal [8] provides the arguments for maintaining such a standpoint. The Deal is the EU's new strategic choice, aiming to successfully transform European national economies, i.e., for them to abandon the existing linear development model and establish a new, sustainable model 
of economic and social development. The plan is to achieve this by executing a series of initiatives serving to protect the environment and promote a green economy.

\section{Materials and Methods}

For the purpose of the research outlined in this paper, the authors used annual data for the following variables:

- Economic indicators

- Total number of employed people

- GDP

- Gross investments

- Environmental indicators

- Wastewater emissions in thousands of $\mathrm{m}^{2}$

$\circ$ tons of $\mathrm{SO}_{2}$ per year

$\circ$ tons of $\mathrm{CO}$ per year

$\circ$ tons of $\mathrm{NO}_{\mathrm{x}}$ per year

These variables were analysed in Croatia for the period from 1996 to 2017. The indicators were drawn from the Croatian Bureau of Statistics, which is sometimes limited in its scope, so some variables were not available for certain years. Croatia gained its independence in 1991, so acquiring any data for a longer period of time was not possible. Furthermore, most environmental indicators have only been tracked since 2003, which is an additional limitation of this research. The statistical analyses were conducted using the STATA 12.0 programme package (StataCorp LLC, College Station, TX, USA), and apart from basic descriptive statistics, the authors also performed correlation and regression analyses. Based on the research interest, the following two hypotheses were formed:

Hypotheses 1 (H1). size of investments caused an increase in GDP and employment.

Hypotheses 2 (H2). size of investments affects environmental indicators.

Based on the research hypotheses, an econometric model was formed where the size of investment was defined as an independent variable, while dependent variables included the total number of employed people, GDP, wastewater emissions in cubic metres, $\mathrm{SO}_{2}, \mathrm{CO}$ and $\mathrm{NO}_{\mathrm{x}}$. The first part of the statistical analysis defined the Pearson correlation between the stated variables, and the second part used the following log-log regression:

$$
\log y_{-} \mathrm{i}=\mid \text { beta_i* }{ }^{*} \backslash \log \mathrm{x} \_\mathrm{i}
$$

where $y_{-} i$ is one of the stated dependent variables and $x$ is the independent variable.

\section{Results}

This paragraph details the results obtained through the conducted analysis. The statistical analysis of variables in the model was conducted first and is shown in Table 3. 
Table 3. Statistical description of variables in the model.

\begin{tabular}{|c|c|c|c|c|c|c|c|}
\hline Stats & $\begin{array}{l}\text { Total Number of Employed } \\
\text { (Thousands) }\end{array}$ & $\begin{array}{c}\text { GDP } \\
\text { (Million Kuna) }\end{array}$ & $\begin{array}{l}\text { Gross Investments } \\
\text { (Million Kuna) }\end{array}$ & $\begin{array}{l}\text { Wastewater Emissions } \\
\text { (Thousands of Cubic Meters) }\end{array}$ & $\begin{array}{c}\mathrm{SO}_{2} \\
\mathrm{t} / \text { Year }\end{array}$ & $\begin{array}{l}\text { CO } \\
\text { t/Year }\end{array}$ & $\begin{array}{l}\mathrm{NO}_{\mathrm{x}} \\
\mathrm{t} / \text { Year }\end{array}$ \\
\hline mean & 1369.087 & $256,931.8$ & 56,900 & $297,058.2$ & $41,879.47$ & $27,0131.8$ & $66,811.33$ \\
\hline $\mathrm{sd}$ & 105.0476 & $90,648.55$ & 21,000 & $57,382.67$ & $23,253.68$ & $67,447.08$ & $10,614.48$ \\
\hline skewness & 0.155488 & -0.35014 & 0.538571 & 0.0917748 & -0.09484 & -0.09272 & -0.03377 \\
\hline kurtosis & 2.311137 & 1.446044 & 2.602548 & 1.782786 & 1.31827 & 1.906935 & 1.447495 \\
\hline JB test $(p)$ & 0.7605 & 0.2641 & 0.5317 & 0.5153 & 0.4086 & 0.6811 & 0.4702 \\
\hline PP test $(p)$ & 0.6559 & 0.6747 & 0.3755 & 0.8135 & 0.8419 & 0.7009 & 0.8697 \\
\hline
\end{tabular}

Legend: JB (Jarque-Bera test; PP (Phillips-Perron test). 
The data shows that the mean value of the total number of employed people is 1369 (thousand). The analysed data shows that the number of employed people has increased in the observed time period until 2009. With the onset of the global economic crisis, the number of employed people in Croatia also started to drop. However, in 2018 the number rose once again to the 2008 level. During the observed period, the number of employed people rose by a mean annual rate of $1.23 \%$. When looking at the GDP we can see that its mean value is around 257 billion kuna. Much like the number of employed people, the GDP was also continuously on the rise until 2009, when it started to fall. The highest GDP in the observed period was noted in 2017, with a mean annual rise of $4.5 \%$. The mean value of investments executed is 56.9 billion kuna, and the highest value was achieved in 2008, after which investments began to drop. Throughout the observed period we see that investments have grown at a mean annual rate of $4 \%$. The highest annual increase was thus observed for the GDP. Economic growth is typically accompanied by increased emissions of harmful matter into the atmosphere. The mean value of wastewater emissions is $297,058.2$, and we can see that it was continuously on the rise until 2013, when it started to decline. The mean value of $\mathrm{SO}_{2}$ is $41,879.79$. In recent years $\mathrm{SO}_{2}$ emissions have been declining, so its numbers have been below the mean value ever since 2011. The mean value for CO emissions is 270,131.8, and numbers below the mean value have been observed starting in 2013. The mean value of $\mathrm{NO}_{x}$ emissions is $66,811.33$, and its numbers have been below the mean value since 2012. The results of the Jarque-Bera test show the normality of all included variables. As we cannot reject the hypothesis that variables contain a unit root, we performed the Johnsen procedure to detect cointegration, to be sure to avoid spurious regression.

A correlation analysis was conducted to determine the relationship between investments and economic indicators, and the Pearson coefficient was calculated (Table 4).

Table 4. Pearson coefficient for the investments variable and economic variables.

\begin{tabular}{ccc}
\hline Indicator & Correlation Coefficient & Significance \\
\hline Employed & 0.8380 & $<0.0001$ \\
GDP & 0.6088 & 0.0026 \\
\hline
\end{tabular}

All variables show a positive link with investment levels, which means that increasing investments can be expected to result in an increase of the other variables. All correlations are statistically significant. Those under 0.3 can be considered weak, i.e., increasing investments will not have too much of an effect on them. Correlations between 0.3 and 0.6 can be considered moderate, and a moderate correlation in this case was observed between investments and GDP. A coefficient above 0.6 indicates a strong correlation, i.e., its impact will be strong, which in this case was observed between investments and number of employed people. It can thus be concluded with high significance that more investments are followed by an increase in the number of employed people and the GDP. In Table 5 a correlation analysis was also done to determine the relationship between investments and environmental indicators.

Table 5. Pearson coefficient for the investments variable and environmental variables.

\begin{tabular}{ccc}
\hline Indicator & Correlation Coefficient & Significance \\
\hline Wastewater & -0.1976 & 0.3905 \\
$\mathrm{SO}_{2}$ & 0.7541 & 0.0012 \\
$\mathrm{CO}$ & 0.6315 & 0.0116 \\
$\mathrm{NO}_{\mathbf{x}}$ & 0.9103 & $<0.0001$ \\
\hline
\end{tabular}

The results show that increasing investments is statistically significantly connected with an increase in pollution when it comes to sulphur, carbon monoxide and nitric oxides, but not when it comes to wastewater emissions. This can be explained by the fact that when Croatia gained its independence in 1991, it immediately adopted laws regulating this area, and has amended the regulation over the years to follow the most current trends in water preservation [69]. Wastewater is likely negative because 
investments made for acquiring water purification equipment did not yield good enough results. In Table 6 is shown results from Univariant regression log-log alanysis.

Table 6. Univariat regression log-log analysis.

\begin{tabular}{cccc}
\hline Indicator & Regression Coefficient & $\mathbf{R}^{\wedge} \mathbf{2}$ & $\boldsymbol{p}$ \\
\hline GDP & 0.771057 & 0.5455 & $<0.0001$ \\
Employed & 0.1743628 & 0.7464 & $<0.0001$ \\
$\mathrm{SO}_{2}$ & 2.178371 & 0.6591 & $<0.0001$ \\
$\mathrm{CO}$ & 0.683595 & 0.4286 & 0.008 \\
$\mathrm{NO}_{\mathrm{x}}$ & 0.5874169 & 0.8541 & $<0.0001$ \\
\hline
\end{tabular}

Since the variables are not stationary, it is necessary to test the cointegration between the variables to avoid the occurrence of spurious regression. In all cases, it was possible to find integration by the Johnsen procedure, except for the relationship between investment and employment, which is also suggested by a relatively high R^2. Therefore, we will not further comment on this relationship.

The analysis conducted shows that raising investments by $1 \%$ on average leads to an increase of:

- $\quad$ GDP by $0.77 \%$

- Number of employed by $0.17 \%$

- Sulphur emissions by $2.1 \%$

- CO emissions by $0.68 \%$

- $\mathrm{NO}_{\mathrm{x}}$ emissions by $0.58 \%$

Based on the results of the analysis it can be concluded that both research hypotheses have been confirmed. An increase in the level of investments results in positive trends regarding the GDP, but the investments also affect environmental indicators. The analysis showed that a rise in investments has a negative impact on the environment, i.e., that greenhouse gas emissions are increased as well, excluding wastewater emissions.

In order to determine how future investments will impact the observed economic indicators, a predictive model was designed based on the analysis conducted that states:

$$
y=x^{\text {coefficient }}
$$

where $x$ are investments, and $y$ is the GDP.

As previously noted, the Republic of Croatia will have 22 billion euro at its disposal in the period from 2021 to 2027, part of which (9.4 billion) comes from the Next Generation EU fund and the rest (12.7 billion) from the European Multiannual Financial Framework (MFF). In accordance with the European Green Deal strategic framework, the criteria for selecting projects to be funded by the MFF will be based on transitioning towards a green economy and the development processes and changes closely tied to it, such as implementing a circular economy in specific fields and sectors, transitioning to sustainable and smart mobility, transitioning to clean energy and more [8,70]. For Croatia this represents both a significant challenge and an opportunity, so the authors have designed two potential scenarios regarding how the MFF investment funds will impact the Croatian GDP and employment, based on the projected available funds in the following budgeting period. Projects funded by the Next Generation EU fund ( 9.4 billion euro) have not been taken into account because those funds are primarily to be used for supporting COVID-19 relief efforts. Additionally, the projection does not include specifically how the funds will impact the environmental indicators. This is because the funds themselves are primarily to be allocated to so-called green projects whose main features include higher resource efficiency, reduction of negative effects on the environment, reduction of negative emissions and climate impact and similar.

In the previous programme period, Croatia used only $40 \%$ of the resources available to the country. Such a low percentage can be explained through inexperience with drawing EU funds and a lack of 
preparation concerning documentation and projects. For the following period, experts in raising funds, ministries and units of local self-government have significant human and administrative resources, so the documentation for all projects to be applied to is mostly already complete. It is therefore expected that the degree to which the resources are used will be much higher. When making their projection on how investing in green economy funded from the MFF will impact the GDP and employment, the authors of this paper took two different starting points. The pessimistic projection predicts that $50 \%$ of the available funds will be used, and the optimistic projections predicts that the amount will be $80 \%$.

Projections were made for the year 2028, i.e., at the end of the programme period. Therefore, in order to predict the impact on the GDP and employment, several assumptions had to be made:

- $60 \%$ of the expected 12.7 billion euro from the MFF will be spent on projects related to green economy. That amounts to 7.62 billion euro available for Croatia for green jobs. According to the EU, these funds are expected to be used for digital transformation, sustainable development, circular economy and projects related to a green economy.

- Out of the $60 \%$, Croatia will only draw a part of the funds. Previous experience has shown that Croatia only drew around $40 \%$. This projection predicts a pessimistic scenario, in which Croatia draws $50 \%$, and an optimistic scenario, with $80 \%$.

- The GDP, investments and employment projections are based on the annual growth rates achieved from 1996 to 2018.

- Formula 2 was used to calculate the projection regarding the impact of green economy project investments on the GDP and employment.

By this assumption it has been made calculation of impact of green economy investments on GDP and number of employes people (Table 7).

Table 7. Impact of green economy investments on the GDP and number of employed people.

\begin{tabular}{ccc}
\hline Category & $\begin{array}{c}\text { Pessimistic Impact Projection } \\
\mathbf{( 5 0 \%} \text { Resources) }\end{array}$ & $\begin{array}{c}\text { Optimistic Impact Projection } \\
\mathbf{( 8 0 \%} \text { Resources) }\end{array}$ \\
\hline BDP increase for 2021-2027 & $4.5 \%$ & $7.1 \%$ \\
Employment increase & $1 \%$ & $1.5 \%$ \\
\hline
\end{tabular}

The results indicate that funds from the European Multiannual Financial Framework used to invest in projects pertaining to a green economy will have exceptionally positive effects. The pessimistic projection shows that those investments would result in a 4.5\% GDP increase and 1\% employment increase. The optimistic projections, which the authors of this paper consider to be realistic and achievable, show that GDP would increase by $7.1 \%$ and employment by $1.5 \%$.

\section{Discussion and Conclusions}

This research proved the positive link between investment values, GDP and employment trends in Croatia, as well as between investments and sulphur, $\mathrm{CO}$ and $\mathrm{NO}_{\mathrm{x}}$ emissions. This paper has thus proven the research by other authors, as presented in the paragraph with the literature review. Furthermore, the scenarios that were developed confirm the possibility of increasing the national output and employment in the EU's next budgeting period (2021-2027) with a part of the investments funded by the European Multiannual Financial Framework. This paper focused on the Croatian transition to a green economy, a transition which lies at the heart of the European Green Deal. It "aims to transform the EU into a fair and prosperous society, with a modern, resource-efficient and competitive economy where there are no net emissions of greenhouse gases in 2050 and where economic growth is decoupled from resource use" [8]. It is thus evident that Croatia will have to make strategic decisions and use concrete projects and investment activities to implement a full spectrum of measures aligned with achieving common EU green objectives, while also structurally changing its economy and increasing its competitiveness. 
In the period 2014-2017 Croatian economy recorded positive trends in GDP (6.7\% increase 2014-2017) and a rise in employment. Nonetheless, out of 28 EU member countries, Croatia only ranks 26th according to GDP [71]. Official statistics [72] show that the majority of investments, circa $30 \%$ over the last three years, related to the processing industry and public management, even though the second highest grossing element of the Croatian GDP is trade. When this is combined with the fact that tourism plays a significant role in employment and income, it can be concluded that Croatian economy is based on a lack of capital and a lack of knowledge-intensive activities, and that the activities it does focus on do not have the potency to be strong predictors of economic growth and development. This is further confirmed by Croatia holding a very low rank on the global competitiveness list. From 2010 to 2018 Croatia was ranked between 77th and 81st on a list of 137-148 observed countries [73]. Based on the Global Competitiveness Index (GCI), the key weaknesses that were identified refer to the lack of innovation capacities and low level of business sophistication. In addition, it should be noted that Croatia also suffers from significant regional inequalities, which keep widening despite numerous government subsidies. This leads to an inefficient use of existing regional and local resources, rural abandonment and a reduction in the quality of life and the quality of public services in insufficiently developed areas. This demographic drain, both nationally and especially in developmentally sensitive areas, is a significant economic and social limitation for development in the future.

Transitioning to a green economy can represent a true opportunity for mitigating all these issues, as a rapid developmental lunge for Croatia. A successful green transition, however, requires changing the structure of future investments in the areas on which the investments are focused. The investments should go into energy transition, building a green infrastructure and green cities, implementing a circular economy, developing eco-innovations, ecological agriculture and more. All those areas still have to be properly conceptualized in terms of instruments and methods. For example, when it comes to implementing a circular economy, Croatia was ranked 20th in 2017, which is $72 \%$ below the EU average per the eco-innovation index [70]. A circular material flow is a key indicator of the implementation of a circular economy, and in Croatia in 2016 it only amounted to $4.4 \%$, while the EU average was $11.7 \%$. Municipal waste generation has been on a slow rise since 2014 at $416 \mathrm{~kg}$ per year per capita compared to the EU average, which is $487 \mathrm{~kg}$ per year per capita. Even though the recycling of municipal waste has grown from 2010 to 2017, it is still only $24 \%$ compared to the EU average of $46 \%$. Illegal waste landfills remain a huge problem.

On the other hand, Croatia has great potential for successfully completing the energy transition when looking at existing natural resources and the possibility of increasing the role of renewable energy sources in the total energy consumption. In 2017 Croatia recorded $27.3 \%$ in gross direct consumption of renewable energy sources when the EU average was $17.5 \%$. Those numbers indicate that the goal of increasing that share to $20 \%$ by the year 2020 was achieved [65]. Energy transition towards low-carbon production and energy consumption should result in an increase in investments in this sector, especially by private investors, as well as a reduction of the operative costs of energy production. As stated in the adopted Energy Development Strategy of the Republic of Croatia until 2030 with an outlook to 2050 [63], the greatest effects are expected to stem from energy efficiency measures (e.g., building renovation), development of electromobility, transportation, production and use of renewable energy sources.

Agriculture is another sector in which Croatia has huge potential for transitioning to a green economy. This includes, for example, developing ecological production and the food industry, that is based on it. Croatia already meets many ecological standards set for EU agriculture in general. A relatively clean environment and GMO-free land are good foundations for a successful agricultural green transition. Furthermore, agricultural potential can take the shape of increasing the amount of arable land and agricultural production to a level that meets the standards of sustainable agriculture. Only $8 \%$ of agricultural land area in Croatia is suitable for growing different cultures. Based on the results, it is thus necessary to invest in agricultural land, which would result in an increase of 
agricultural production and employment. Existing research shows that agriculture is especially suitable for new green jobs such as family farms or small businesses based on various forms of green agriculture.

Transitioning in this sector should increase the amount of available domestic and medically safe food products whose production is not a threat to the environment. Taking into account the previously discussed issue of regional divergence in Croatia, the agricultural transition to a green economy could potentially be highly beneficial for rural and underdeveloped areas. For example, eastern Croatia has long been behind most developmental indicators compared to national numbers, and it faces large-scale depopulation, especially among the young and among families. At the same time, eastern Slavonia is rich in natural resources, unused agricultural land and renewable energy sources. Implementing the concept and policies of green economy can slow down developmental lag and secure economic and social development in the long-term while simultaneously preserving the region's environment [74]. Furthermore, a green transition in agriculture contributes to realizing the EU's "From Field to Fork" strategy, which is one of the key elements of the European Green Deal and the framework for big changes in agriculture [2].

Tourism also plays an important role in Croatian economy, both from the perspectives of employability and standard of life, and from the perspective of budget income. The importance of tourism for the Croatian economy is clear when looking at the numbers-tourism expenditures over the total GDP are $22.8 \%$, the direct tourism impact on the GDP is $11.4 \%$, and tourism employs $8.2 \%$ of the workforce $[75,76]$. The period of the COVID crisis has made it clear how dangerous it is to rely too much on tourism and how vulnerable the sector is. At the same time, the features of tourism include high labour intensity, seasonality and relatively low employee wages. Moreover, it is a huge source of environmental pollution. These are all arguments pointing towards the need to transform the Croatian tourism sector to a so-called green tourism, in order to significantly reduce the pressure that tourism exerts on the environment in the future, and all in order to ensure its environmental sustainability [68]. According to the Global Sustainable Tourism Criteria [77], transitioning towards green tourism cannot focus only on reducing the negative environmental impact. It must also focus on efficiently planning for the sustainable development of tourism, maximizing social economic benefits for the local community and enhancing cultural heritage. Implementing the green economy concept into Croatian tourism is expected to yield significant macroeconomic results. For example, green tourism development has multiple benefits for employment. Firstly, it creates an additional market for all suppliers of green technologies and services (waste management, energy efficiency, green planning and management, green civil engineering, etc.). Secondly, it aims to increase revenue not through physical growth, but by providing a higher quality and additional offer that expands the length of the season, thus creating the jobs required for additional tourism services. Such jobs are either tied to the tourism offer directly (specialized tourist agencies, tourist guides) or are necessary for creating the environment in which such a tourism offer and quality is made possible (creative industries, cultural industries, green civil engineering, eco-design, permaculture, sustainable mobility and more).

These are some of the examples of the possible results of Croatian economy transitioning to a green economy, viewed through specific activities and sectors. However, to ensure a full and successful transition and to achieve the goals laid out in the European Green Deal, it will be necessary to transform a whole spectrum of policies. There is economy in general-energy, industry, agriculture, good, civil engineering, total production and spending. There are also infrastructural policies, transportation, finance, taxes and social policies. This future transition has to include increasing the value of preserving and restoring the ecosystem, sustainable resource consumption and improving people's health [78]. It is expected that the systematic implementation of the concept and policies of the green economy will result in an increased demand for new green jobs and specific knowledge, and ensure long-term green growth in particular sectors and the economy in general. When looking at the timeframe after the 2021-2027 EU budgeting period, the authors think that the rise of employment and national output will be even higher than what the two projections laid out in this paper predict. This optimism stems 
from the fact that Croatia is already equipped with numerous strategic documents that clearly lay out a developmental vision for the transition to a green economy.

It is furthermore evident that concrete green projects will be funded and encouraged not just when it comes to EU funds, but also by national, regional and local funds, and especially resources from the private sector.

Finally, it should be noted that "the green economy is a highly complex construct in terms of its attempts to integrate economic, environmental, and social concerns, the wide range of actors involved, its material outcomes, and the forms of governance needed to regulate processes of economic greening" [48]. Such complexity represents a challenge for scientists and experts. It also invites further theoretical research, as well as empirical solutions for developing a sustainable model for creating a social and environmental future for particular countries, Croatia included.

Author Contributions: N.D.B.: paper concept, literature review, introduction, discussion and conclusion; Z.S.G.: methodology, research results, literature review. All authors have read and agreed to the published version of the manuscript.

Funding: The publication of this paper has been supported by University of Rijeka under the projects: "Smart cities in function of development of national economy" (uniri-drustv-18-255-1424); "Impact of intangible capital in Croatian economy" (uniri-drustv-18-166) and "Circular economy-the possibility of Croatian economic development" (ZP UNIRI 6/18).

Acknowledgments: We thank 3 independent reviewers and the Editor for the helpful comments that have substantially improved the clarity of the manuscript.

Conflicts of Interest: The authors declare no conflict of interest. The founding sponsors had no role in the design of the study; in the collection, analyses, or interpretation of data; in the writing of the manuscript, and in the decision to publish the results.

\section{References}

1. Malaval, F. Complexity, Entropy Production and Industrial Ecology, Institute du Management des Eco-Innovations (Durables). 2008. Available online: http://frederic-malaval.wifeo.com/documents/ Complexity-entropy-production-and-Industrial-ecology.pdf (accessed on 15 July 2020).

2. European Commission. Europe 2020—A Strategy for Smart, Sustainable and Inclusive Growth, COM (2010), Final. March 2010. Available online: https://ec.europa.eu/eu2020/pdf/COMPLET\%20EN\%20BARROSO\% $20 \% 20 \% 20007 \% 20-\% 20$ Europe $\% 202020 \% 20$ - 20 EN\%20version.pdf (accessed on 1 July 2020).

3. Guo, M.; Nowakowska-Grunt, J.; Gorbanyov, V.; Egorova, M. Green Technology and Sustainable Dvelopment: Assessment and Green Growth Frameworks. Sustainability 2020, 12, 6571. [CrossRef]

4. Karaman Aksentijević, N.; Denona Bogović, N.; Ježić, Z. Ekonomika Razvoja; Sveučilište u Rijeci, Ekonomski Fakultet: Rijeka, Croatia, 2019; pp. 50-125. Available online: https://www.efri.uniri.hr/upload/knjiznica/E\% 20izdanja/Ekonomika\%20razvoja_online\%20izdanje.pdf (accessed on 14 September 2020).

5. Liu, N.; Liu, C.; Xia, Y.; Ren, Y.; Liang, J. Examining the Coordination Between Green Finance and Green Economy Aiming for Sustainable Development: A Case Study of China. Sustainability 2020, 12, 3717. [CrossRef]

6. Moreno, B.; Garcia-Alvarez, M.T. Measuring the progress towards a resource-efficient European Union under the Europe 2020 Strategy. J. Clean. Prod. 2018, 170, 991-1005. [CrossRef]

7. European Commission. Towards a Sustainable Europe by 2030. 2019. Available online: https://op.europa. eu/en/publication-detail/-/publication/3b096b37-300a-11e9-8d04-01aa75ed71a1/language-en/format-PDF (accessed on 14 September 2020).

8. European Commission. The European Green Deal. 2019. Available online: https://eur-lex.europa.eu/legalcontent/EN/TXT/?qid=1576150542719\&uri=COM\%3A2019\%3A640\%3AFIN (accessed on 14 September 2020).

9. Jurčić, L. Hrvatsko gospodarstvo i svjetsko okruženje. Ekonomski Pregled 2016, 67, 605-636.

10. Sverko Grdic, Z.; Gregoric, M.; Krstinic Nizic, M. Investigating the Influence of Tourism on Economic Growth and Climate Change-The Case of Croatia. Contemp. Econ. 2019, 13, 111-122. [CrossRef]

11. Loiseau, E.; Saikku, L.; Antikainen, R.; Droste, N.; Hansjürgens, B.; Pitkänen, K.; Leskinen, P.; Kuikman, P.; Thomsen, M. Green Economy and related concepts: An overview. J. Clean. Prod. 2016, 139, 361-371. [CrossRef] 
12. UNEP. Towards a Green Economy: Pathways to Sustainable Development and Poverty Eradication. 2011. Available online: https://sustainabledevelopment.un.org/content/documents/126GER_synthesis_en.pdf (accessed on 15 September 2020).

13. Vuola, M.; Korkeakoski, M.; Vähäkari, N.; Dwyer, M.B.; Hogarth, N.J.; Kaivo-Oja, J.; Luukkanen, J.; Chea, E.; Thuon, T.; Phonhalath, K. What is a Green Economy? Review of National-Level Green Economy Policies in Cambodia and Lao PDR. Sustainability 2020, 12, 6664. [CrossRef]

14. UNDESA. A Guidebook to the Green Economy Issue 1: Green Economy, Green Growth, and Low-Carbon Development-History, Definitions and a Guide to Recent Publications Division for Sustainable Development. 2012. Available online: http://www.greentouches-uae.com/MediaFiles/DownloadFile/40c90618-8253-498fa55c-73ff8c110dd6.pdf (accessed on 15 September 2020).

15. Saikku, L.; Antikainen, R.; Droste, N. Implementing the Green Economy in a European Context Lessons Learned from Theories, Concepts and Case Studies; Partnership for European Environmental Research (PEER): Helsinki, Finland, 2015; pp. 1-36.

16. Kasztelan, A. Green Growth, Green Economy and Sustainable Development: Terminological and Relational Discourse. Prague Econ. Pap. 2017, 26, 487-499. [CrossRef]

17. Pearce, D.W.; Markandya, A.; Barbier, E. Blueprint for a Green Economy; Earthscan: London, UK, 1989; pp. 123-154.

18. Le Blanc, D. Special issue on green economy and sustainable development. Nat. Resour. Forum 2011, 35, 151-154. [CrossRef]

19. Pearce, D.W. Greening the World Economy; Earthscan: London, UK, 1991; pp. 50-75.

20. Pearce, D.; Hamilton, K.; Atkinson, G. Measuring Sustainable Development: Progress on Indicators. Environ. Dev. Econ. 1996, 1, 85-101.

21. Musango, J.K.; Brent, A.C.; Bassi, A.M. Modelling the transition towards a green economy in South Africa. Tehnol. Forecast. Soc. Chang. 2014, 87, 257-273. [CrossRef]

22. Pollin, R. Advancing a Viable Global Climate Stabilization Project: Degrowth versus the Green New Deal. Rev. Radic. Political Econ. 2019, 51, 311-319. [CrossRef]

23. Green Economy Initiative. Available online: https://www.unsystem.org/content/unep-led-green-economyinitiative (accessed on 15 August 2020).

24. Morrow, K. Rio+20, the Green Economy and Re-Orienting Sustainable Development. Environ. Law Rev. 2012, 14, 279-297. [CrossRef]

25. Poltarykkin, A.L. Prospects for the Development of the Green Economy of Russian Federation. Eur. Res. Stud. J. 2018, 21, 470-479. [CrossRef]

26. Wanner, T. The New 'Passive Revolution' of the Green Economy and Growth Discourse: Maintaining the 'Sustainable Development' of Neoliberal Capitalism. New Political Econ. 2015, 20, 21-41. [CrossRef]

27. Clémençon, R. Welcome to the Anthropocene: Rio+20 and the meaning of sustainable development. J. Environ. Dev. 2012, 21, 311-338. [CrossRef]

28. Halle, M. Life after Rio: A Commentary by Mark Halle, IISD. 2012. Available online: https://www.iisd.org/ sites/default/files/publications/com_life_after_rio.pdf (accessed on 15 August 2020).

29. Barbier, E.B. The green economy post Rio+20. Science 2013, 338, 887-888. [CrossRef]

30. Bonsinetto, F.; Falco, E. Analysing Italian regional patterns in green economy and climate change. Can Italy leverage on Europe 2020 strategy to face sustainable growth challenges? J. Urban Reg. Anal. 2013, 2, 123-142. [CrossRef]

31. Davies, A.R. Cleantech clusters: Transformational assemblages for a just, green economy or just business as usual? Glob. Environ. Chang. 2013, 23, 1285-1295. [CrossRef]

32. Deutsche Gesellschaft fur Internationale Zusammenarbet (GIZ). GIZ Progress Report on Sustainability 2015. 2016. Available online: https:/www.giz.de/en/downloads/giz2015-en-progress-report-sustainability.pdf (accessed on 10 August 2020).

33. Ge, Y.; Zhi, Q. Literature Review: The Green Economy, Clean Energy Policy and Employment. Energy Procedia 2016, 88, 257-264. [CrossRef]

34. Borel-Saladin, J.M.; Turok, I.N. The impact of the green economy on jobs in South Africa. S. Afr. J. Sci. 2013, 109, 253-270. [CrossRef]

35. Atlama, S.; Ozsoy, C. The Possible Effects of Green Economy on Employment. In Proceedings of the Anadolu International Conference in Economics II, Eskisehir, Turkey, 15-17 June 2011. 
36. Aldieri, L.; Vinci, C.P. Green Economy and Sustainable Development: The Economic Impact of Innovation on Employment. Sustainability 2018, 10, 3541. [CrossRef]

37. Gagliardi, L.; Marin, G.; Miriello, C. The greener the better? Job creation effects of environmentally-friendly technological change. Ind. Corp. Chang. 2016, 25, 779-807. [CrossRef]

38. Pociovălișteanu, D.M.; Novo-Corti, I.; Aceleanu, M.I.; Șerban, A.C.; Grecu, E. Employment Policies for a Green Economy at the European Union Level. Sustainability 2015, 7, 9231-9250. [CrossRef]

39. Hickel, J.; Kallis, G. Is Green Growth Possible? J. New Political Econ. 2020, 25, 469-486. [CrossRef]

40. Nahman, A.; Muhamani, B.K.; Lange, W.J. Beyond GDP: Towards a Green Economy Index. Dev. South. Afr. 2016, 33, 215-233. [CrossRef]

41. European Commission. European Commission-Basics Green Economy. 2016. Available online: https: //enrd.ec.europa.eu/sites/enrd/files/publi-enrd-rr-23-2017-en.pdf (accessed on 26 September 2020).

42. Gissin, V.I.; Mekhantseva, K.F.; Putilin, T.I.; Surzhikov, M.A. Green Economy: Emerging National Models, Estimations, Trends in EU and CIS. Eur. Res. Stud. J. 2018, 21, 156. [CrossRef]

43. Brand, U. Green economy-The Next Oxymoron? No Lessons Learned from Failures of Implementing Sustainable Development. Ecol. Perspect. Sci. Soc. 2012, 21, 28-32. [CrossRef]

44. Lorek, S.; Spangenberg, J.H. Sustainable Consumption Within a Sustainable Economy-Beyond Green Growth and Green Economies. J. Clean. Prod. 2014, 63, 33-44. [CrossRef]

45. Green, K.P. The Myth of Green Energy Jobs: The European Experience. American Enterprise Institute for Public Policy Research. 2011; No. 1. Available online: https:/www.aei.org/research-products/report/themyth-of-green-energy-jobs-the-european-experience/ (accessed on 17 September 2020).

46. Alvarez, G.C. Study of the Effects on Employment of P Aid to Renewable Energy Sources.Universidad Rey Juan Carlos. 2009. Available online: https://instituteforenergyresearch.org/wp-content/uploads/2015/05/ 090327-employment-public-aid-renewable.pdf (accessed on 17 September 2020).

47. Bailey, I.; Caprotti, F. The Green Economy: Functional Domains and Theoretical Directions of Enquiry. Environ. Plan. 2014, 46, 1797-1813. [CrossRef]

48. Boyd, E.; Boykoff, M.; Newell, P. The 'New' Carbon Economy: What's New? Radic. J. Geogr. Antipod. 2011, 43, 601-611. [CrossRef]

49. Cook, S.; Smith, K. Introduction: Green Economy and Sustainable Development: Bringing back the social. Soc. Int. Dev. 2012, 55, 5-9. [CrossRef]

50. Jude, C.; Silaghi, M.I.P. Employment effects of foreign direct investment: Now evidence from Central and Eastern European Countires. Intern. Econ. 2016, 145, 32-49. [CrossRef]

51. Skufina, T.; Baranov, S.; Samarina, V.; Shatalova, T. Production Functions in Identifying the Specifics of Producing Gross Regional Product of Russian Federation. Mediterr. J. Soc. Sci. 2015, 6, 265-270. [CrossRef]

52. Guo, L.I.; Qu, Y.; Tseng, M.L. The interaction effects of environmental regulation and technological innovation on regional green growth performance. J. Clean. Prod. 2017, 162, 894-902. [CrossRef]

53. Kim, S.E.; Kim, H.; Chae, Y. A new approach to measuring green growth: Application to the OECD and Korea. Futures 2014, 63, 37-48. [CrossRef]

54. Mundaca, L.; Roman, R.; Cansino, J.M. Towards a green energy economy? A macroeconomics climate evaluation of weden's $\mathrm{CO}_{2}$ emissions. Appl. Energy 2015, 148, 196-209. [CrossRef]

55. Bilagev, A.; Dong, S.; Li, F.; Cheng, H.; Sadykova, E.; Mikhevva, A. Assessment of the Current Eco Social Economic Situation of the Baikal Region (Russia) from the Perspective of the Green Economy Development. Sustainability 2020, 12, 3767. [CrossRef]

56. Chao, A.C.; Hong, L. Corporate Social Responsibility Strategy, Environment and Energy Policy. Struct. Chang. Econ. Dynamnics 2019, 51,311-317. [CrossRef]

57. Ohori, S. Price and Quantity Competition in a Miced Duoploy with Emission Tax. Theor. Econ. Lett. 2014, 4, 133-138. [CrossRef]

58. Di Segni, D.; Huly, M.; Akron, S. Corporate social responsibility, environmental leadership and financial performance. Soc. Responsib. J. 2015, 11, 131-148. [CrossRef]

59. Hartley, K.; Santen, R.; Kirchherr, J. Policies for transitioning towards a circular economy: Expectations from the European Union. Resour. Conserv. Recycl. 2020, 155, 104634. [CrossRef]

60. Strategy for Sustainable Development of the Republic of Croatia. O.G. 30/2009. 2007. Available online: https://narodne-novine.nn.hr/clanci/sluzbeni/2009_03_30_658.html (accessed on 16 September 2020). 
61. Strategic Determinants for the Development of the Green Economy - Green Development of Croatia. Ministry of Environmental Protection, Physical Planning and Construction. 2011. Available online: https://vlada.gov.hr/ UserDocsImages//2016/Sjednice/Arhiva//117153.\%20-\%201.3.pdf (accessed on 16 September 2020).

62. Strategy for Innovation Encouragement of the Republic of Croatia 2014-2020. O.G. 153/2014. 2014. Available online: https://narodne-novine.nn.hr/clanci/sluzbeni/dodatni/434155.pdf (accessed on 15 September 2020).

63. Smart Specialisation Strategy of the Republic of Croatia for the Period from 2016 to 2020. O.G. 32/2016. 2016. Available online: https://narodne-novine.nn.hr/clanci/sluzbeni/2016_04_32_853.html (accessed on 17 September 2020).

64. Strategy for the Energy Development of Croatia in the Period until 2030 with an Outlook for the Period until 2050. O.G. 25/2020. 2020. Available online: https://narodne-novine.nn.hr/clanci/sluzbeni/full/2020_03_25_ 602.html (accessed on 17 September 2020).

65. Law of Islands in the Republic of Croatia RH. O.G. 73/20. 2018. Available online: https://www.zakon.hr/z/ 638/Zakon-o-otocima (accessed on 14 September 2020).

66. Law on Hilly and Mountainous Areas. O.G. 118/18. 2019. Available online: https://www.zakon.hr/z/754/ Zakon-o-brdsko-planinskim-podru\%C4\%8Djima (accessed on 22 September 2020).

67. Ministry of Tourism, Institute for Tourism. Action Plan for Green, Development of Tourism; Ministry of Tourism, Institute for Tourism: Zagreb, Croatia, 2016. Available online: https://mint.gov.hr/UserDocsImages/arhiva/ 160715_AP_Zelenog_t.pdf (accessed on 15 September 2020).

68. Integrated National Energy and Climate Plan for the Period 2021-2030. Ministry of Environmental Protection and Energetics. 2019. Available online: https://mzoe.gov.hr/UserDocsImages/UPRAVA\% 20ZA\%20ENERGETIKU/Strategije,\%20planovi\%20i\%20programi/hr\%20necp/Integrirani\%20nacionalni\% 20energetski\%20i\%20klimatski\%20plan\%20Republike\%20Hrvatske\%20\%20_final.pdf (accessed on 23 September 2020).

69. The Water Act, O.G. 66/19. Available online: https://narodne-novine.nn.hr/clanci/sluzbeni/2019_07_66_1285. html (accessed on 15 September 2020).

70. European Commission. Circular Economy Action Plan. 2020. Available online: https://ec.europa.eu/ environment/circular-economy/index_en.htm (accessed on 25 September 2020).

71. Eurostat. Available online: https://ec.europa.eu/eurostat/tgm/table.do?tab=table\&init=1\&language=en\& pcode $=$ sdg_08_10\&plugin $=1$ (accessed on 25 September 2020).

72. Statistical Yearbook of Croatia 2016, 2017, 2018. Croatian Bureau of Statistic. Available online: www.dzs.hr (accessed on 25 September 2020).

73. World Economic Forum. Available online: www.weforum.org (accessed on 14 September 2020).

74. Denona Bogović, N.; Drezgić, S.; Čegar, S. Green Economy as a Development Model of Eastern Croatia. In Proceedings of the 5th International Scientific Symposium "The Economy of eastern Croatia-Vision and Growth", Osijek, Croatia, 2-4 June 2016.

75. Country Fact Sheet. Available online: https://webunwto.s3.eu-west-1.amazonaws.com/s3fs-public/2020-10/ croatia.pdf (accessed on 14 September 2020).

76. Tourism in Numbers 2019. Ministry of tourism Republic of Croatia. 2020. Available online: https://www.htz.hr/ sites/default/files/2020-07/HTZ\%20TUB\%20HR_\%202019\%20\%281\%29.pdf (accessed on 25 September 2020).

77. GSTC - Global Sustainable Tourism Council Global Sustainable Tourism. Council Criteria and Suggested Performance Indicators for Hotels and Tour Operators. 2013. Available online: http://www.gstcouncil.org (accessed on 25 September 2020).

78. Holy, M. Instrumenti Zelene Tranzicije: Održivi Razvoj, Cirkularna, Bioekonomijai Kreativna Ekonomija; Friedrich-Ebert-Stiftung: Zagreb, Croatia, 2020.

Publisher's Note: MDPI stays neutral with regard to jurisdictional claims in published maps and institutional affiliations.

(C) 2020 by the authors. Licensee MDPI, Basel, Switzerland. This article is an open access article distributed under the terms and conditions of the Creative Commons Attribution (CC BY) license (http://creativecommons.org/licenses/by/4.0/). 